Portland State University

PDXScholar

\title{
Multistate Mark-Recapture Analysis Reveals No Effect of Blood Sampling on Survival and Recapture of Eastern Kingbirds (Tyrannus Tyrannus)
}

\author{
Lucas J. Redmond \\ Michael T. Murphy \\ Portland State University, murphym@pdx.edu
}

Follow this and additional works at: https://pdxscholar.library.pdx.edu/bio_fac

Part of the Animals Commons, Biology Commons, and the Ornithology Commons

Let us know how access to this document benefits you.

\section{Citation Details}

Redmond, L. J., \& Murphy, M. T. (2011). Multistate mark-recapture analysis reveals no effect of blood sampling on survival and recapture of Eastern Kingbirds (Tyrannus tyrannus). The Auk, 128(3), 514-521.

This Article is brought to you for free and open access. It has been accepted for inclusion in Biology Faculty Publications and Presentations by an authorized administrator of PDXScholar. Please contact us if we can make this document more accessible: pdxscholar@pdx.edu. 


\title{
MULTISTATE MARK-RECAPTURE ANALYSIS REVEALS NO EFFECT OF BLOOD SAMPLING ON SURVIVAL AND RECAPTURE OF EASTERN KINGBIRDS (TYRANNUS TYRANNUS)
}

\author{
LuCAS J. ReDmond ${ }^{1}$ and Michael T. Murphy \\ Department of Biology, P.O. Box 751, Portland State University, Portland, Oregon 97207, USA
}

\begin{abstract}
The experimentally supported and prevailing opinion is that blood sampling has few to no long-term effects on survival of birds when conducted properly, and blood sampling has become a vital addition to the toolbox of many ornithologists. However, many of the studies that concluded that blood sampling had negligible effects on birds used approaches that did not account for temporary emigration and probability of capture. To date, the only study to have done so found that blood sampling had a strong negative effect on survival. We conducted a mark-recapture analysis of 8 years of banding and bleeding data on Eastern Kingbirds (Tyrannus tyrannus) to determine whether survival was negatively influenced by blood sampling. Our analyses adjusted for temporary emigration and probability of recapture and accounted for (1) transitions between the bled and the nonbled state and (2) a change in protocol roughly midway through the study that resulted in a change from single to often multiple (and larger) draws of blood per year from single individuals. We found that survival rates of nonbled (0.61) and bled (0.67) males were statistically indistinguishable and that bled females had a higher probability of survival than nonbled females ( 0.68 and 0.58 , respectively). The change to larger and more frequent blood samples was also not associated with a change in survival. Our data show that when accepted protocols were followed, blood sampling had no detectable influence on the survival of adult Eastern Kingbirds. Whether this applies generally awaits analyses using similarly rigorous methods on other species. Received 29 December 2010, accepted 30 March 2011.
\end{abstract}

Key words: blood sampling, detectability, Eastern Kingbird, mark-recapture, multistate model, survival, Tyrannus tyrannus.

\section{Análisis Multiestado de Marcado-Recaptura Revela Ausencia de Efectos de la Toma de Muestras de Sangre sobre la Supervivencia y Recaptura de Tyrannus tyrannus}

RESUMEN.-Una opinión prevalente que ha sido apoyada experimentalmente es que la toma de muestras de sangre tiene pocos o ningún efecto de largo plazo sobre la supervivencia de las aves cuando se hace adecuadamente. Además, el muestreo de sangre se ha convertido en una adición vital a la caja de herramientas de muchos ornitólogos. Sin embargo, muchos de los estudios que concluyeron que la toma de muestras de sangre tenía efectos despreciables sobre las aves emplearon enfoques que no tuvieron en cuenta la emigración temporal ni la probabilidad de captura. A la fecha, el único estudio que tuvo en cuenta estos factores encontró que la toma de muestras de sangre tenía un efecto negativo fuerte sobre la supervivencia. Realizamos un análisis de marcado-recaptura de 8 años de datos de anillado y toma de muestras en Tyrannus tyrannus para determinar si la supervivencia era influenciada negativamente por la toma de muestras de sangre. Nuestros análisis fueron ajustados de acuerdo a la emigración temporal y a la probabilidad de recaptura y tuvieron en cuenta (1) las transiciones entre el estado de aves a las que les tomaron sangre y las que no, y (2) un cambio en protocolo más o menos a la mitad del estudio, que llevó a un cambio de una sola a frecuentemente varias (y más grandes) tomas de sangre por año en aves individuales. Encontramos que las tasas de supervivencia de los machos a los que no se les tomaron muestras de sangre (0.61) y de los machos a los que sí se les tomaron muestras (0.67) fueron estadísticamente indistinguibles, y que las hembras a las que se les tomaron muestras de sangre presentaron una mayor probabilidad de supervivencia que las hembras a las que no se les tomaron muestras (0.68 y 0.58, respectivamente). El cambio a muestras más grandes y más frecuentes tampoco se asoció con un cambio en la supervivencia. Nuestros datos demuestran que cuando se siguieron protocolos aceptados, la toma de muestras de sangre no tuvo una influencia detectable sobre la supervivencia de individuos adultos de T. tyrannus. Para establecer la generalidad de este hallazgo, es necesario hacer análisis empleando métodos rigurosos similares en otras especies.

With THE RELATIVE ease and affordability of modern laboratory techniques, increasing numbers of field biologists regularly collect blood samples from their study organisms to extract DNA for behavioral studies (Dolan et al. 2007, Balenger et al. 2009); to measure metabolites (Lyons et al. 2008, Lobato et al. 2010), hormones (Spinney et al. 2006, Van Hout et al. 2010), or stable isotopes (Studds

${ }^{1}$ E-mail: luk916@hotmail.com

The Auk, Vol. 128, Number 3, pages 514-521. ISSN 0004-8038, electronic ISSN 1938-4254. @ 2011 by The American Ornithologists' Union. All rights reserved. Please direct all requests for permission to photocopy or reproduce article content through the University of California Press's Rights and Permissions website, http://www.ucpressjournals. com/reprintInfo.asp. DOI: 10.1525/auk.2011.10289 
and Marra 2005, Beaulieu et al. 2010); or to conduct immunological research (Hatch et al. 2010, Knowles et al. 2010). Although the widespread use of these techniques has opened many new and exciting lines of inquiry, with the increased regularity of blood collection comes an increased need for researchers to ensure that they safely handle birds and minimize threats to survival. Loss of blood resulting from collection of a blood sample can cause an immediate decline in blood volume, which, in turn, can lead to a drop in blood pressure and cardiac output, which results in increased heart rate. Blood volume has the potential to be restored relatively quickly by absorption of extracellular fluids, but hemodilution will occur because lost red blood cells require at least 30 days to be replaced (Rodnan et al. 1957). This may lead to short-term anemia (Ploucha et al. 1981, Fair et al. 2007), which may have longer-term effects on survival because of decreases in hematocrit, hemoglobin, or plasma proteins.

To ameliorate any long-term effects that the loss of blood may have on survival, researchers are advised to collect a sample smaller than some previously determined maximum volume. For example, the Ornithological Council's Guidelines to the Use of Wild Birds in Research (Fair et al. 2010) recommends that $\leq 2 \%$ of the total body mass of an animal be collected as blood over the span of 2 weeks and that $\leq 1 \%$ be collected at any one time. The evidence to date (summarized by Sheldon et al. 2008) largely suggests that when these guidelines are followed, the collection of blood has no long-term effect on individual survival.

However, the papers included in Sheldon et al.'s (2008) review are not without shortcomings that, to some extent, weaken the conclusion that blood sampling has no effect on survival. First, in many of these studies, the intervals over which survival was monitored were relatively short, ranging from a few days to months (Franks 1967, Raveling 1970, Utter et al. 1971, Bigler et al. 1977, Frederick 1986, Stangel 1986, Ardern et al. 1994), which may not have been sufficient to detect a decrease in survivorship of bled individuals. Second, and perhaps more importantly, all the studies that were conducted on free-living individuals, regardless of length, measured and reported recapture rates of bled versus nonbled individuals (previous references, Wingfield and Farner 1976, Colwell et al. 1988, Dufty 1988, Hoysak and Weatherhead 1991, Perkins et al. 2004). Even in a simple survival analysis, failure to take the probability of recapture and of temporary emigration from the study area into account can lead to inaccurate estimates of survival (Martin et al. 1995). A better approach is to utilize methods that account for recapture probabilities and temporary emigration, such as the Cormack-Jolly-Seber (CJS) model (Cormack 1964, Jolly 1965, Seber 1965) and generalizations of this model, such as multistate capturerecapture models (Arnason 1972, 1973; Schwarz et al. 1993). The latter would be the more appropriate choice for determining whether drawing blood increases the probability of death, because multistate models, unlike the traditional CJS model, allow for categorical variables that may change over an individual's life (e.g., a state variable such as whether or not a blood sample was drawn).

Recently, Brown and Brown (2009) used multistate mark-recapture models to show that, contrary to the conclusions drawn from previously published studies, blood sampling had a dramatic negative effect on the survival of Cliff Swallows (Petrochelidon pyrrhonota). These results drew attention to the long-held assumption that blood sampling does not have long-term detrimental effects on survival. However, the peculiarities of each study species and research site deem it essential that more studies be conducted to determine the generality of Brown and Brown's (2009) results in the Cliff Swallow. Here, we use data from a population of color-banded Eastern Kingbirds (Tyrannus tyrannus; hereafter "kingbirds") to address the potential effects of blood sampling on survival. We have individually banded and drawn blood from kingbirds over an 8-year period in association with demographic work and studies of extrapair paternity (Dolan et al. 2007, 2009; L. J. Redmond unpubl. data). All birds had a blood sample drawn at their initial encounter, which was followed by recaptures within the same and subsequent years, during which blood may or may not have been drawn. Moreover, for males, the volume of the blood sample and the frequency with which individuals were sampled were increased roughly midway through our study, in conjunction with other studies. We used these data within a multistate mark-recapture framework to determine whether blood sampling negatively affected survival of adult kingbirds.

\section{Methods}

Study site.-We conducted the study on a color-banded population of kingbirds at Malheur National Wildlife Refuge in southeastern Oregon $\left(42^{\circ} 49^{\prime} \mathrm{N}, 118^{\circ} 54^{\prime} \mathrm{W}\right)$ from 2002 to 2009 . Kingbirds on the refuge breed primarily in the riparian areas created by the Donner und Blitzen River and its associated secondary watercourses. Beginning in mid-May, we conducted daily surveys by vehicle of the riparian areas of the refuge along a $\sim 45-\mathrm{km}$ stretch of the river beginning at Paige Springs Campground at the southern end of the refuge. The Center Patrol Road closely parallels (3-5 m distance) the river throughout most of the study site, and this provided direct access to foraging and nesting habitats. Any suitable areas away from the river but within our overall study area were also visited to maximize the probability that we encountered previously marked kingbirds. Kingbirds show very high site-fidelity (Murphy 1996b, Redmond et al. 2009). Given that, and our thorough coverage of the portion of the refuge that defined our study site, we are confident that we encountered most marked birds.

Adult males were captured throughout the breeding season using a recording of a kingbird dawnsong that was played back near a mist net during the predawn period, when the male we were trying to capture was singing. Females and, to a lesser extent, males were captured at the nest while feeding young. After capture, a blood sample was taken using a sterile needle via brachial venipuncture, and we then measured body mass, wing chord, and tarsus, bill, and tail lengths. Each individual was banded with one numbered federal band and a unique combination of three-colored plastic bands. Total handling time was $\sim 20$ min for each bird. Blood samples were taken initially to provide DNA for studies of parentage, and, therefore, individuals were recaptured only if they were incidentally caught while we attempted to capture another individual, or if the bird had to be recaptured to replace a lost color band. This was the case for females throughout the study, but beginning in 2005 we also began to recapture males both within and between years to draw multiple blood samples to describe seasonal variation in testosterone and to examine the relationship between individual variation in testosterone and extrapair mating success. Therefore, the frequency of blood sampling increased in the latter half of our study (both within and among years for individuals), and the volume taken (for males) increased from $\sim 60 \mu \mathrm{L}$ 
to as much as $250 \mu \mathrm{L}$. Regardless of the volume taken, the mass of the volume of blood sample $(0.06-0.25 \mathrm{~g})$ was below the suggested $1 \%$ maximum of total body mass, given the average body mass of the kingbirds that we sampled ( $=39 \mathrm{~g}$ and thus $0.39 \mathrm{~g}$ ).

Data preparation.-We constructed multistate capture histories for color-banded kingbirds in the population. Multistate models were originally designed to represent movement and survival among different populations (e.g., Hestbeck et al. 1991, Breininger et al. 2009) but can be adapted for use with other types of categorical variables that could change over time (e.g., reproductive status or effort; Lescroel et al. 2009, Schaub and von Hirschheydt 2009). The state values in our models indicated whether or not blood was collected from an individual in a year. We also included a group variable in the capture histories to describe an individual's sex. To be included in our data set, blood must have been collected from an individual at least once when it was an adult. Because blood was collected from all individuals that were initially captured as adults, by default they were all included in the data set and we used their entire capture history (modified to match state values). We also included individuals that were banded as nestlings, but only if the individual was captured and also bled at least once as an adult. For this subset of individuals, we slightly modified the capture histories to eliminate variation in survival following initial capture between individuals banded as nestlings and adults (i.e., juvenile and adult survival). This was done by modifying capture histories such that individuals banded as nestlings were not considered "alive" (a value other than zero in the capture history) until they were captured and bled as adults.

Model-selection procedure.-We used the "multi-strata recaptures only" option in Program MARK (White and Burnham 1999) and in M-SURGE, version 1.8.5 (Choquet et al. 2004), to compare models. We performed a goodness-of-fit (GOF) test on a global model that was fully time-, state-, and group-dependent for all parameters using U-CARE, version 2.3.2 (Choquet et al. 2009). All GOF tests were nonsignificant, which indicated that the models that we tested fit the data adequately. Therefore, we used Akaike's information criterion adjusted for small sample size (AIC C $_{\mathrm{c}}$ ) as the criterion for model selection and concluded that models were well supported by the data when $\Delta \mathrm{AIC}_{\mathrm{c}}<7$. We used Akaike weights $\left(w_{i}\right)$ to derive weighted estimates of parameter values (Burnham and Anderson 2002), which are given as the estimate \pm SE and $95 \%$ confidence intervals (CI). We considered overlap in $95 \%$ CIs of one parameter with the estimated mean of another parameter as evidence that the two did not differ.

In order to minimize the number of models in the candidate set and avoid model redundancy, model comparison occurred in stages (e.g., Franklin et al. 2004), in which variation of model structure for each parameter (survival, recapture, and transition probabilities) was confined to a single stage. The order in which the stages were conducted was based on both an increase in biological relevance of the parameters, given our data set, and the questions of most importance for our analyses. In our models, transition probability between states (whether or not blood was drawn) was dependent on our ability to capture an individual and had no real biological meaning. Thus, the best-fitting model for transition probability was carried over to the second stage. Recapture probability was dependent on our ability to resight individuals, and we considered the possibility that collecting blood from an individual had an effect on recapture in the following year. The best-fitting model for recapture probability was carried over to the third, and final, stage. The primary purpose of these analyses was to determine whether collecting blood from an individual had an effect on survival; thus, survival probability was the parameter of most interest.

Model structure and hypotheses.-Transition between states for our models indicated whether or not blood was collected from an individual in a given year. Because this parameter has no real biological relevance, we were less interested in testing specific hypotheses than in finding a model whose structure best explained variation in the data and minimized the number of estimable parameters for transition probability. We considered a total of eight models for transition probability, the most general of which ( $\Psi[$ sex*b_D]) was sex-dependent and structured to account for changes in our blood-sampling protocol. Blood samples were required for DNA analyses only between 2002 and 2004 (Dolan et al. 2007), but from 2005 through 2009 we collected multiple blood samples from males for hormone assays (L. J. Redmond unpubl. data). Thus, we considered a set of models whose structure reflected the difference in frequency with which males and females were sampled. Several simplified models of varying structure were also compared, the simplest being $\Psi($.), in which transition probability was constant between states and the sexes.

We compared six models for recapture probability (Table 1). To test for an effect of blood sampling on recapture probability in the following year, we used Jolly-Move models (JMV; Brownie et al.1993). Because MARK does not include JMV models, we used M-SURGE to complete this step of the analyses. Unlike the conditional Arnason-Schwarz model (CAS; Arnason 1972, Schwarz et al. 1993) in which recapture probabilities are dependent only on the current state, JMV models also consider the previous state. Thus, a JMV model was the most appropriate type of multistate model to test the hypothesis that blood sampling affected recapture probability of kingbirds. The most general model that we considered was a sex-dependent JMV model (p[sex*b]-JMV). We also considered a second JMV model that was sex-independent but also state-dependent (p[b]-JMV). These two models tested the hypothesis that blood sampling had an effect on future recapture probability, which, if supported, would suggest that birds dispersed beyond the limits of our study site in the year after they were bled. We compared the JMV models with four others that did not account for variation in recapture probability due to the previous blood-sampling state. Two of these were the CAS versions of the JMV models (p[sex*b]-CAS, $\mathrm{p}[\mathrm{b}]-\mathrm{CAS})$, and the other two were state-independent but sex-dependent $(\mathrm{p}[\mathrm{sex}])$ and an interceptonly model (p[.]).

The most general model for survival probability (S[sex*b_D]) that we considered was sex- and state-dependent, the latter being structured to account for the change in blood-sampling protocol in the same way that we adjusted for transition probability. This structure was important because it accounted for the potential increase in the frequency of blood collection from an individual and the increase in the volume of the sample taken. Because the change in protocol was largely restricted to males, we included a male-only model, as for transition probability. We also included a subset of models that were state-dependent but that did not account for changes in blood-sampling protocol. Finally, two models 
TABLE 1. Notation and description of models tested for recapture ( $p$ ) and survival $(\mathrm{S})$ probabilities of Eastern Kingbirds at Malheur National Wildlife Refuge, Oregon, 2002-2009.

\begin{tabular}{|c|c|c|}
\hline Parameter & Model & Description \\
\hline \multirow[t]{6}{*}{$\mathrm{p}$} & sex*b-JMV & $\begin{array}{l}\text { Tests for differences in p between sexes and blood-sampling states (b). Both previous and current states were } \\
\text { considered. }\end{array}$ \\
\hline & sex*b-CAS & $\begin{array}{l}\text { Tests for differences in p between sexes and blood-sampling states. Unlike in the previous model, only the current state } \\
\text { was considered. }\end{array}$ \\
\hline & b-JMV & Tests for differences in p between states. Both previous and current states were considered. \\
\hline & b-CAS & Tests for differences in p between states. Unlike in the previous model, only the current state was considered. \\
\hline & sex & Tests for differences in $\mathrm{p}$ between sexes. \\
\hline & . & Null model. No difference in $p$ between sexes or states. \\
\hline \multirow[t]{11}{*}{ S } & sex*b_D & Tests for difference in S between sexes and states. Further tests for a difference (D) in S between sampling protocols used. \\
\hline & sex*b_D-m & As above, but difference in sampling protocol is only tested among males $(\mathrm{m})$, not females. \\
\hline & sex*b_l & $\begin{array}{l}\text { Tests for a difference between sexes and an initial decrease in survival in interval (I) following sampling, but intervals } \\
\text { thereafter are the same as for nonbled state. }\end{array}$ \\
\hline & sex*b & Tests for differences in $\mathrm{S}$ between sexes and states. \\
\hline & b_D & Tests for difference between states and the sample protocol used. \\
\hline & b_D-m & As above, but protocol difference for sampled males only. \\
\hline & b_l & $\begin{array}{l}\text { Tests for an initial decrease in survival in interval following sampling, but intervals thereafter are the same as for } \\
\text { nonbled state. }\end{array}$ \\
\hline & b_m & Tests for difference between states, but for males only. \\
\hline & $b^{-}$ & Tests for differences in $\mathrm{S}$ between states. \\
\hline & sex & Tests for differences in S between sexes. \\
\hline & . & Null model. No difference in $\mathrm{S}$ between sex or state. \\
\hline
\end{tabular}

were constructed (one sex-dependent, the other not) that tested for an initial effect of blood sampling on survival, but assumed that subsequent sampling events had no effect. All these models assumed differences in survival between bled and nonbled states and could be compared with models that were state-independent. In the set of models that we tested, we included a sex-dependent model and a null model that was sex- and state-independent. In all, 11 models of survival probability were fit to the data. Results are presented as means \pm SE.

\section{Results}

From 2002 to 2009, a total of 247 adult kingbirds (152 males and 95 females) fit the criteria that we deemed necessary for inclusion in the analyses of the relationship between blood sampling and survival. Of these, 214 were initially captured and bled as adults, and the remaining 33 were banded as nestlings but later captured and bled as adults. Within years, the number of individuals captured and bled ranged from 21 to 62, with a maximum for individuals of 3 and 1 blood draws for males and females, respectively. Across all years, blood was collected from individual males (maximum $=8$ times, mean $=1.50 \pm 0.07$ ) more frequently than from females (maximum $=4$ times, mean $=1.30 \pm 0.06 ; t=2.23, \mathrm{df}=245, P=0.026$ ).

Transition probability.-Transition probabilities between blood-sampling states were best explained by a model that accounted for differences in sampling protocol for males only (Table 2). This model was retained for the following stage, in which recapture probabilities were modeled.

Recapture probability.-The JMV models (p[sex*b]-JMV, $\mathrm{p}[\mathrm{b}]-J M V)$ that tested for an effect of blood sampling on recapture probability received very little support from the data $\left(\Delta \mathrm{AIC}_{\mathrm{c}} \geq\right.$ 11.98; Table 2). The best-fitting models $\left(\Delta \mathrm{AIC}_{\mathrm{c}}<7\right)$, instead, were a model that was structured to account for differences between the sexes (p[sex]; $\left.\Delta \mathrm{AIC}_{\mathrm{c}}=0.0\right)$ and a CAS-type model (p[sex*b]-CAS; $\left.\Delta \mathrm{AIC}_{\mathrm{c}}=0.55\right)$ that included a sex*state interaction. The former was retained for the stage in which survival probability was modeled. Model-averaged estimates of recapture probability also indicated that there was no statistical difference between recapture rates of bled and nonbled individuals of either sex (Table 3).

Survival probability.-According to the $\Delta \mathrm{AIC}_{\mathrm{c}}$ values, all models of survival probability were relatively well supported by the data, which indicates a substantial amount of model-selection uncertainty (Table 2). The best-fitting model (S[b] p[sex] $\Psi$ [b_D-m]) predicted a difference in survival probability between bled and nonbled states. The other competing model (S[sex*b_I] p[sex] $\Psi$ [b_D-m]) also predicted a difference between states, but only for the interval immediately following the individual's first blood sample, with estimates of survival during subsequent intervals being the same as for nonbled individuals. However, the state-specific estimates of survival probability for both of these models were not consistent with the hypothesis that blood sampling had a negative effect on survival. For model (S[b] p[sex] $\Psi$ [b_D-m]), annual survival probability of bled individuals was $0.689 \pm 0.029$ (95\% CI: 0.630-0.742), compared with $0.575 \pm 0.034$ (95\% CI: 0.506-0.641) for nonbled individuals. Single-model estimates from (S[sex*b_I] $\mathrm{p}[\mathrm{sex}] \Psi\left(\left[\mathrm{b} \_\mathrm{D}-\mathrm{m}\right]\right)$ indicated no differences between bled $(0.646 \pm$ 0.040; 95\% CI: 0.564-0.720) and nonbled males (0.659 \pm 0.038 ; 95\% CI: 0.581-0.728). Female estimates from this model were different: bled females survived at higher rates $(0.732 \pm 0.057 ; 95 \%$ CI: $0.610-0.829)$ than nonbled individuals $(0.546 \pm 0.047 ; 95 \% \mathrm{CI}$ : 0.453-0.635).

The model that tested the hypothesis that changes in bloodsampling protocol (i.e., larger and more frequent draws of blood from males from 2005 onward) had negative consequences for 
TABLE 2. Results of model selection for transition $(\Psi)$, recapture $(p)$, and survival probabilities (S) with respect to sex and blood-sampling state (b) for Eastern Kingbirds breeding at Malheur National Wildlife Refuge, Oregon, 2002-2009. For p, "CAS" in model notation indicates that this parameter was modeled using the conditional Arnason-Schwarz method and "JMV" denotes the Jolly-Move model. Blood-sampling state was structured further to account for differences in sampling protocol for both sexes (b_D) and for males only (b_D-m; see text for description) and to reflect a one-time effect of blood sampling on survival (b_l). $w_{i}=\mathrm{AIC}_{\mathrm{c}}$ weight, $k=$ number of parameters.

\begin{tabular}{|c|c|c|c|c|c|c|}
\hline Stage & Model & $\mathrm{AICc}$ & $\Delta \mathrm{AIC}_{\mathrm{c}}$ & $w_{i}$ & k & $-2 \log (\mathrm{L})$ \\
\hline \multirow[t]{8}{*}{$\Psi$} & $S\left(s e x * b \_D-m\right) p(s e x * b) \Psi\left(b \_D-m\right)$ & $1,134.58$ & 0.00 & 0.33 & 14 & $1,104.77$ \\
\hline & S(sex*b_D-m) p(sex*b) $\Psi\left(\operatorname{sex}^{*} b \_D-m\right)$ & $1,134.76$ & 0.18 & 0.30 & 16 & $1,100.39$ \\
\hline & S(sex*b_D-m) p(sex*b) $\Psi(b)$ & $1,134.41$ & 0.83 & 0.22 & 12 & $1,109.08$ \\
\hline & S(sex*b_D-m) p(sex*b) $\Psi($ b_D $)$ & $1,137.10$ & 2.51 & 0.09 & 15 & $1,105.02$ \\
\hline & $S\left(s^{*}{ }^{*} b \_D-m\right) p\left(\operatorname{sex}^{*} b\right) \Psi\left(\operatorname{sex}^{*} b\right)$ & $1,138.14$ & 3.55 & 0.06 & 14 & $1,108.33$ \\
\hline & S(sex*b_D-m) p(sex*b) $\Psi\left(\right.$ sex$^{*}$ b_D $)$ & $1,142.64$ & 8.05 & 0.01 & 20 & $1,098.92$ \\
\hline & S(sex*b_D-m) p(sex*b) $\Psi()$. & $1,178.03$ & 43.44 & 0.00 & 11 & $1,154.91$ \\
\hline & S(sex*b_D-m) p(sex*b) $\Psi($ sex $)$ & $1,180.12$ & 45.53 & 0.00 & 12 & $1,154.79$ \\
\hline \multirow[t]{6}{*}{$\mathrm{p}$} & $S\left(\right.$ sex*b_D-m) p(sex) $\Psi\left(b \_D-m\right)$ & $1,134.03$ & 0.00 & 0.52 & 13 & $1,106.47$ \\
\hline & S(sex*b_D-m) p(sex*b)-CAS $\Psi\left(b \_D-m\right)$ & $1,134.58$ & 0.55 & 0.46 & 14 & $1,104.77$ \\
\hline & $S\left(s e x * b \_D-m\right) p(b)-C A S \Psi\left(b \_D-m\right)$ & $1,141.65$ & 7.62 & 0.01 & 12 & $1,116.32$ \\
\hline & S(sex*b_D-m) p(.) $\Psi($ b_D-m) & $1,142.23$ & 8.20 & 0.01 & 12 & $1,116.90$ \\
\hline & S(sex*b_D-m) p(sex*b)-JMV $\Psi\left(b \_D-m\right)$ & $1,146.01$ & 11.98 & 0.00 & 20 & $1,102.29$ \\
\hline & $S\left(s e x * b \_D-m\right) p(b)-J M V \Psi\left(b \_D-m\right)$ & $1,146.82$ & 12.79 & 0.00 & 16 & $1,112.45$ \\
\hline \multirow[t]{11}{*}{ S } & $\mathrm{S}(\mathrm{b}) \mathrm{p}(\mathrm{sex}) \Psi\left(\mathrm{b} \_\mathrm{D}-\mathrm{m}\right)$ & $1,128.03$ & 0.00 & 0.30 & 9 & $1,109.27$ \\
\hline & $\mathrm{S}\left(\right.$ sex*b_l) $\mathrm{p}(\mathrm{sex}) \Psi\left(\mathrm{b} \_\mathrm{D}-\mathrm{m}\right)$ & $1,129.62$ & 1.59 & 0.14 & 10 & $1,108.69$ \\
\hline & $S\left(b \_D\right) p(s e x) \Psi\left(b \_D-m\right)$ & $1,130.08$ & 2.03 & 0.11 & 10 & $1,109.15$ \\
\hline & $S() p.($ sex $) \Psi\left(b \_D-m\right)$ & $1,130.07$ & 2.04 & 0.11 & 7 & $1,115.60$ \\
\hline & $S\left(b \_l\right) p(s e x) \Psi\left(b \_D-m\right)$ & $1,130.31$ & 2.28 & 0.10 & 8 & $1,113.70$ \\
\hline & $S($ sex*b) p(sex) $\Psi($ b_D-m) & $1,130.38$ & 2.35 & 0.09 & 11 & $1,107.26$ \\
\hline & $S($ sex $) p($ sex $) \Psi\left(b \_D-m\right)$ & $1,131.56$ & 3.54 & 0.05 & 8 & $1,114.95$ \\
\hline & $S\left(b \_m\right) p(s e x) \Psi\left(b \_D-m\right)$ & $1,132.32$ & 4.30 & 0.04 & 9 & $1,113.56$ \\
\hline & S(sex*b_D-m) p(sex) $\Psi($ b_D-m) & $1,132.46$ & 4.44 & 0.03 & 12 & $1,107.13$ \\
\hline & S(sex*b_D) p(sex) $\Psi\left(b \_D-m\right)$ & $1,134.03$ & 6.00 & 0.02 & 13 & $1,106.47$ \\
\hline & $S\left(b \_D-m\right) p(s e x) \Psi\left(b \_D-m\right)$ & $1,134.39$ & 6.37 & 0.01 & 10 & $1,113.46$ \\
\hline
\end{tabular}

TABLE 3. Model-averaged parameter estimates ( \pm SE) for recapture $(p)$ and survival (S) probabilities of Eastern Kingbirds at Malheur National Wildlife Refuge, Oregon, 2002-2009. Parameter estimates were calculated using all models in the candidate set from their respective stages in the model-selection process. The volume of blood sample that was collected changed between 2004 and 2005, which is reflected under males (the amount collected from females was inconsistent, but mostly remained small).

\begin{tabular}{lllcc}
\hline Parameter & Sex & State & Estimate & $95 \% \mathrm{Cl}$ \\
\hline$p$ & Male & Bled & $0.981 \pm 0.009$ & $0.814-0.999$ \\
& Nonbled & $0.956 \pm 0.022$ & $0.843-0.989$ \\
& Female & Bled & $0.743 \pm 0.061$ & $0.312-0.946$ \\
& & Nonbled & $0.916 \pm 0.025$ & $0.598-0.988$ \\
$S$ & Male & Bled (all individuals) & $0.669 \pm 0.034$ & $0.584-0.744$ \\
& & Small volume & $0.669 \pm 0.035$ & $0.584-0.744$ \\
& Large volume & $0.669 \pm 0.033$ & $0.584-0.746$ \\
& Nonbled & $0.608 \pm 0.034$ & $0.513-0.695$ \\
& \multirow{2}{*}{ Female } & Bled & $0.685 \pm 0.037$ & $0.571-0.781$ \\
& & Nonbled & $0.575 \pm 0.036$ & $0.475-0.674$ \\
\hline
\end{tabular}


survival (S[b_D] p[sex] $\Psi$ [b_D-m]) was also supported $\left(\triangle \mathrm{AIC}_{\mathrm{c}}=\right.$ 2.03). Parameter estimates from this model were again inconsistent with the hypothesis that drawing blood negatively influenced survival. Individuals from which a large sample (2005 and on) was collected had survival probabilities $(0.694 \pm 0.038$; $95 \%$ CI: $0.616-$ 0.763 ) virtually identical to those of individuals from which a small sample (2002-2004) was collected $(0.681 \pm 0.043$; 95\% CI: $0.592-$ 0.759). Although models that were variations of this hypothesis did not perform as well, their model-specific estimates all suggested the same general pattern: an increase in sampling frequency and in the volume of blood per sample had no effect on survival probability. Of the models that did not test for a difference between blood-sampling states, the model (S[.] p[sex] $\Psi$ [b_D-m]) received the most support $\left(\triangle \mathrm{AIC}_{\mathrm{c}}=2.04\right)$ and produced an estimate of survival probability of $0.639 \pm 0.210$ (95\% CI: 0.596-0.680). Given the likelihood of modelselection uncertainty, we used all the models in the data set to generate weighted estimates of survival probability (Table 3). Overall, model-averaged estimates exhibited a similar pattern as previously shown: state-specific survival estimates for males did not differ, and although survival estimates for bled females were higher, they were likely not different from those for nonbled females.

\section{DiscusSION}

Every individual included in our study was bled when first captured. Therefore, the transition that we modeled, which was the basis for our comparisons of bled and nonbled birds, was a bird's treatment in subsequent captures. This design standardized individuals to the same initial state and helped control for unknown past histories for each individual. With this design, we found little to no evidence that blood sampling adversely affected kingbirds.

Aside from direct effects on survival, some have proposed that blood sampling could potentially lead to an increase in dispersal behavior (Voss et al. 2010), which would manifest itself as a lower probability of recapture of sampled than of nonsampled individuals. Our study and that of Brown and Brown (2009) are the only ones that have calculated recapture probabilities of nonbled and bled birds, and neither study found a difference. Recaptureresighting probability of male kingbirds was uniformly high $(p \geq 0.96)$ regardless of blood-sampling state, which is consistent with previous studies that have shown that male kingbirds are extremely site-faithful (Murphy 1996b, Redmond et al. 2009). Females disperse more than males (Murphy 1996b), which is the most likely explanation for why the overall recapture probability (independent of state) was lower in females. Although the 95\% CI of the recapture probability of bled females did not overlap the male estimates, the recapture probability of nonbled females did. Among females, the model-averaged estimate of recapture rate for bled and nonbled individuals fell within each other's 95\% CI, and, thus, they did not differ. Finally, the JMV models provided no support for the hypothesis that resighting probability differed between bled and nonbled birds.

Collecting blood also had no negative effect on the survival of kingbirds. The nearly identical survival rates (based on overlap of estimates and 95\% CIs) of bled (0.67) and nonbled males (0.61) generally place them toward the upper end of survival rates for Nearctic-Neotropical migrants (Brown and Brown 1996, Gardali et al. 2003), which is consistent with the conclusion that there is little reason to suspect that our handling of these birds negatively affected survival. We do not deny that blood sampling has an immediate effect on the physiology of the individual sampled (reviewed by Sheldon et al. 2008, Voss et al. 2010) and that, when sampling is done improperly, these effects may manifest themselves as long-term negative consequences for survival. However, when the recommended protocols are followed, as suggested by Fair et al. (2010), our results suggest that any negative effects of blood sampling can be avoided.

Brown and Brown (2009) proposed several explanations for the negative effect of blood sampling on Cliff Swallows. First, hemodilution may induce a number of changes in physiology, which may ultimately affect an individual's capacity for work. This may be especially important for aerial foragers, such as Cliff Swallows, because of their very high daily energy expenditure (Bryant 1997). Second, the trauma associated with the act of collecting blood can cause hematomas in the wing (when blood is collected via brachial venipuncture) or, potentially, muscle strain that may physically limit flight ability. Again, this may be of special concern for aerially foraging species. Blood lost to the formation of hematomas also represents an additional, but unknown, volume that may add to the volume of blood lost to sample collection, which, in some instances, may push the total blood loss beyond acceptable limits. Similarly, simultaneous blood loss through sample collection and by some other route (e.g., ectoparasites) could have a synergistic effect and tip the scales, so to speak, so that an individual incurs a negative effect. Many of the Cliff Swallow colonies in the Browns' study were heavily parasitized. The Browns applied an insecticide to reduce the load of hematophagous ectoparasites, and nonfumigated colonies were often those in which the effect of blood sampling was largest. Moreover, Voss et al. (2010) proposed that limited water availability at the Browns' arid Nebraska study site may have exacerbated the effects of fluid loss associated with collection of blood samples.

Kingbirds and Cliff Swallows are both long-distance migrants that overwinter south of the equator, in South America (Brown and Brown 1995, Murphy 1996a). Aerial foraging, albeit of different styles, also characterizes both species. Comparisons of the two might therefore help evaluate the merits of the hypotheses that have been offered as potential explanations for why blood sampling seemed to negatively affect Cliff Swallow survival. Kingbirds are aerial hawking specialists (Fitzpatrick 1980) that capture single prey by a direct flight that is initiated from a perch. Cliff Swallows are aerial "filterers" that capture numerous small prey during a protracted flight. Kingbirds almost certainly spend less time in flight than Cliff Swallows, but nearly all of a kingbird's diet is obtained on the wing as they capture prey in high-speed flights (Murphy 1987). Thus, if short-term effects of blood sampling as a result of hemodilution or a hindrance to flight performance due to the formation of hematomas or muscle strain caused the poor survival of bled Cliff Swallows, it seems that bled kingbirds should have experienced the same and exhibited lower survival. That we did not find this casts doubt on the possibility that aerial foragers are of special concern and, in general, does not support the idea that short-term declines in physiological performance drove the survival difference between bled and nonbled Cliff Swallows. We also believe that we can eliminate Voss et al.'s (2010) proposal that the arid Nebraska study site may have contributed to the reduced survival of bled birds because our study site, located in the Great Basin Desert, is considerably drier than the Browns' Nebraska site. 
Two very noteworthy differences between Cliff Swallows and kingbirds is body size and the level of ectoparasitism that they experience. Kingbirds are $\sim 75 \%$ heavier than Cliff Swallows. Conceivably, larger birds are better able to tolerate the loss of blood and stress of being handled. However, the absence of any bodysize effect in data summarized by Sheldon et al. (2008) makes this seem unlikely. On the other hand, an influence of ectoparasites seems plausible. The heavy parasite loads that Cliff Swallows experience (Brown et al. 1995) are a far cry from the low-level infestations of hematophagous ectoparasites that adult kingbirds occasionally exhibit. Broods of kingbird young have only rarely been lost to severe infestations of ectoparasites, and, on the whole, ectoparasitism does not appear to be a severe or common problem for kingbirds (Murphy 1996a). The consequences of ectoparasitism for Cliff Swallow biology are very high, as evidenced by the Browns' long-term studies of the species and its parasites (Brown et al. 1995, Brown and Brown 1996). Thus, we suggest this as the most likely explanation for the different responses of the two species to the drawing of blood. Regardless, the discrepancy in results and the importance of this issue further highlight the need for a more focused examination of the effect of blood sampling on survival across a broad range of species, and we encourage the use of multistate mark-recapture analyses to address this important question.

\section{ACKNOWLEDGMENTS}

We thank the Malheur National Wildlife Refuge staff, and especially Refuge Biologist R. Roy, for supporting our work at the refuge. C. and A. Elshoff provided living space, advice, and friendship during our time at Malheur. Financial support for the work was provided by Portland State University, the American Museum of Natural History's Frank M. Chapman Fund, the American Ornithologists' Union Research Awards program, and a National Science Foundation grant (IOB-0539370) to M.T.M.

\section{Literature Cited}

Ardern, S. L., I. G. Mclean, S. Anderson, R. Maloney, and D. M. LAMBERT. 1994. The effects of blood sampling on the behavior and survival of the endangered Chatham Island Black Robin (Petroica traverse). Conservation Biology 8:857-862.

Arnason, A. N. 1972. Parameter estimates for mark-recapture experiments on two populations subject to migration and death. Researches on Population Ecology 13:99-113.

Arnason, A. N. 1973. The estimation of population size, migration rates, and survival in stratified populations. Researches on Population Ecology 15:1-8.

Balenger, S. L., L. S. Johnson, H. L. MAys, JR., AND B. S. Masters. 2009. Extra-pair paternity in the socially monogamous Mountain Bluebird Sialia currucoides and its effect on the potential for sexual selection. Journal of Avian Biology 40:173-180.

Beaulieu, M., Y. Ropert-Coudert, Y. Le Maho, A. Ancel, And F. CRISCUOlo. 2010. Foraging in an oxidative environment: Relationship between $\delta^{13} \mathrm{C}$ values and oxidative status in Adelie penguins. Proceedings of the Royal Society of London, Series B 277:1087-1092.
Bigler, W. J., G. L. Hoff, And L. A. SCribner. 1977. Survival of Mourning Doves unaffected by withdrawing blood samples. BirdBanding 48:168.

Breininger, D. R., J. D. Nichols, G. M. Carter, And D. M. Oddy. 2009. Habitat-specific breeder survival of Florida Scrub-jays: Inference from multistate models. Ecology 90:3180-3189.

Brown, C. R., And M. B. Brown. 1995. Cliff Swallow (Petrochelidon pyrrhonota). In The Birds of North America Online (A. Poole, Ed.). Cornell Lab of Ornithology, Ithaca, New York. [Online.] Available at bna.birds.cornell.edu/bna/species/149.

Brown, C. R., AND M. B. Brown. 1996. Coloniality in the Cliff Swallow: The Effect of Group Size on Social Behavior. University of Chicago Press, Chicago, Illinois.

Brown, C. R., M. B. Brown, ANd B. RANnAla. 1995. Ectoparasites reduce long-term survival of their avian host. Proceedings of the Royal Society of London, Series B 262:313-319.

Brown, M. B., AND C. R. Brown. 2009. Blood sampling reduces annual survival in Cliff Swallows (Petrochelidon pyrrhonota). Auk 126:853-861.

Brownie, C., J. E. Hines, J. D. Nichols, K. H. Pollock, And J. B. HestBeCK. 1993. Capture-recapture studies for multiple strata including non-Markovian transitions. Biometrics 49:1173-1187.

Bryant, D. M. 1997. Energy expenditure in wild birds. Proceedings of the Nutrition Society 56:1025-1039.

Burnham, K. P., And D. R. Anderson. 2002. Model Selection and Multimodel Inference: A Practical Information-Theoretic Approach, 2nd ed. Springer-Verlag, New York.

Choquet, R., J.-D. Lebreton, O. Gimenez, A.-M. Reboulet, And R. PRADEL. 2009. U-CARE: Utilities for performing goodness of fit tests and manipulating CApture-REcapture data. Ecography 32:1071-1074.

Choquet, R., A.-M. Reboulet, R. Pradel, O. Gimenez, and J.-D. LEBRETON. 2004. M-SURGE: New software specifically designed for multistate capture-recapture models. Animal Biodiversity and Conservation 27:207-215.

Colwell, M. A., C. L. Gratto, L. W. Oring, and A. J. Fivizzani. 1988. Effects of blood sampling on shorebirds: Injuries, return rates, and clutch desertions. Condor 90:942-945.

Cormack, R. M. 1964. Estimates of survival from the sighting of marked animals. Biometrika 51:429-438.

Dolan, A. C., M. T. Murphy, L. J. Redmond, and D. Duffield. 2009. Maternal characters and the production and recruitment of sons in the Eastern Kingbird (Tyrannus tyrannus). Behavioral Ecology and Sociobiology 63:1527-1537.

Dolan, A. C., M. T. Murphy, L. J. Redmond, K. Sexton, and D. DUfFIELD. 2007. Extra-pair paternity and the opportunity for sexual selection in a socially monogamous passerine. Behavioral Ecology 18:985-993.

Dufty, A. M., JR. 1988. The effects of repeated blood sampling on survival in Brown-headed Cowbirds. Condor 90:939-941.

Fair, J., E. Paul, And J. Jones, Eds. 2010. Guidelines to the Use of Wild Birds in Research. Ornithological Council, Washington, D.C.

Fair, J., S. Whitaker, ANd B. Pearson. 2007. Sources of variation in haematocrit in birds. Ibis 149:535-552.

FitzPatrick, J. W. 1980. Foraging behavior of Neotropical tyrant flycatchers. Condor 82:43-57. 
Franklin, A. B., R. J. Gutierrez, J. D. Nichols, M. E. Seamans, G. C. White, G. S. Zimmerman, J. E. Hines, T. E. Munton, W. S. LaHaye, J. A. Blakesley, and others. 2004. Population dynamics of the California Spotted Owl (Strix occidentalis occidentalis): A meta-analysis. Ornithological Monographs, no. 54.

FrANKS, E. C. 1967. Mortality of bled birds as indicated by recapture rate. Bird-Banding 38:125-130.

FREDERICK, P. C. 1986. Parental desertion of nestlings by White Ibis (Eudocimus albus) in response to muscle biopsy. Journal of Field Ornithology 57:168-173.

Gardali, T., D. C. Barton, J. D. White, and G. R. Geupel. 2003. Juvenile and adult survival of Swainson's Thrush (Catharus ustulatus) in coastal California: Annual estimates using capture-recapture analyses. Auk 120:1188-1194.

Hatch, M. I., R. J. Smith, And J. C. Owen. 2010. Arrival timing and hematological parameters in Gray Catbirds (Dumetella carolinensis). Journal of Ornithology 151:545-552.

Hestbeck, J. B., J. D. Nichols, ANd R. A. Malecki. 1991. Estimates of movement and site fidelity using mark-resight data of wintering Canada Geese. Ecology 72:523-533.

Hoysak, D. J., and P. J. Weatherhead. 1991. Sampling blood from birds: A technique and an assessment of its effect. Condor 93:746-752.

JoLly, G. M. 1965. Explicit estimates from capture-recapture data with both death and immigration-stochastic model. Biometrika 52:225-247.

Knowles, S. C. L., M. J. Wood, AND B. C. Sheldon. 2010. Contextdependent effects of parental effort on malaria infection in a wild bird population, and their role in reproductive trade-offs. Oecologia 164:87-97.

Lescroel, A., K. M. Dugger, G. Ballard, ANd D. G. Ainley. 2009. Effects of individual quality, reproductive success and environmental variablility on survival of a long-lived seabird. Journal of Animal Ecology 78:798-806.

Lobato, E., J. Moreno, S. Merino, J. Morales, G. Tomás, J. Martínez, R. A. VÁsquez, A. Kuchar, E. Möstl, and J. L. Osorno. 2010. Arrival date and territorial behavior are associated with corticosterone metabolite levels in a migratory bird. Journal of Ornithology 151:587-597.

Lyons, J. E., J. A. Collazo, and C. G. Guglielmo. 2008. Plasma metabolites and migration physiology of Semipalmated Sandpipers: Refueling performance at five latitudes. Oecologia 155:417-427.

Martin, T. E., J. Clobert, And D. R. Anderson. 1995. Return rates in studies of life history evolution: Are biases large? Journal of Applied Statistics 22:863-875.

Murphy, M. T. 1987. The impact of weather on kingbird foraging behavior. Condor 89:721-730.

Murphy, M. T. 1996a. Eastern Kingbird (Tyrannus tyrannus). In The Birds of North America Online (A. Poole, Ed.). Cornell Lab of Ornithology, Ithaca, New York. [Online.] Available at bna.birds. cornell.edu/bna/species/253.

Murphy, M. T. 1996b. Survivorship, breeding dispersal and mate fidelity in Eastern Kingbirds. Condor 98:82-92.

Murphy, M. T. 1987. The impact of weather on kingbird foraging behavior. Condor 89:721-730.
Perkins, K. A., R. R. Roth, J. L. Bowman, and J. Green. 2004. Flushing, capture, and bleeding do not affect return rate of female Wood Thrushes (Hylocichla mustelina) in Delaware. Auk 121:354-360.

Ploucha, J. M., J. B. Scott, And R. K. Ringer. 1981. Vascular and hematologic effects of hemorrhage in the chicken. American Journal of Physiology 240:H9-H17.

Raveling, D. G. 1970. Survival of Canada Geese unaffected by withdrawing blood samples. Journal of Wildlife Management 34:941-943.

Redmond, L. J., M. T. Murphy, A. C. Dolan, and K. Sexton. 2009. Public information facilitates habitat selection of a territorial species: The Eastern Kingbird. Animal Behaviour 77:457-463.

Rodnan, G. P., F. G. Ebaugh, JR., M. R. Spivey Fox, and D. M. Chambers. 1957. The life span of the red blood cell and the red blood cell volume in the chicken, pigeon and duck as estimated by the use of $\mathrm{Na}_{2} \mathrm{Cr}^{51} \mathrm{O}_{4}$ : With observations on red cell turnover rate in the mammal, bird and reptile. Blood 12:355-366.

SCHAUB, M., AND J. vON HiRSCHHEYDT. 2009. Effect of current reproduction on apparent survival, breeding dispersal, and future reproduction in Barn Swallows assessed by multistate capture-recapture models. Journal of Animal Ecology 78:625-635.

Schwarz, C. J., J. F. Schweigert, and A. N. Arnason. 1993. Estimating migration rates using tag-recovery data. Biometrics 49:177-193.

Seber, G. A. F. 1965. A note on the multiple-recapture census. Biometrika 52:249-259.

Sheldon, L. D., E. H. Chin, S. A. Gill, G. Schmaltz, A. E. M. NewMAN, AND K. K. SOMA. 2008. Effects of blood collection on wild birds: An update. Journal of Avian Biology 39:369-378.

Spinney, L. H., G. E. Bentley, AND M. HaU. 2006. Endocrine correlates of alternative phenotypes in the White-throated Sparrow (Zonotrichia albicollis). Hormones and Behavior 50:762-771.

STANGEL, P. W. 1986. Lack of effects from sampling blood from small birds. Condor 88:244-245.

Studds, C. E., And P. P. Marra. 2005. Nonbreeding habitat occupancy and population processes: An upgrade experiment with a migratory bird. Ecology 86:2380-2385.

Utter, J. M., E. A. LeFebvre, and J. S. Greenlaw. 1971. A technique for sampling blood from small passerines. Auk 88:169-171.

Van Hout, A. J.-M., M. Eens, V. M. Darras, And R. PinXten. 2010. Acute stress induces a rapid increase of testosterone in a songbird: Implications for plasma testosterone sampling. General and Comparative Endocrinology 168:505-510.

Voss, M., D. Shutler, And J. Werner. 2010. A hard look at blood sampling of birds. Auk 127:704-708.

White, G. C., And K. P. Burnham. 1999. Program MARK: Survival estimation from populations of marked animals. Bird Study 46 (Supplement):S120-S138.

Wingfield, J. C., And D. S. Farner. 1976. Avian endocrinologyField investigations and methods. Condor 78:570-573.

Associate Editor: K. G. Smith 